\title{
Studies of $\mathrm{Sr}^{2+}$ ion substitution on ferroelectric and piezoelectric properties of PZT nanocrystalline
}

\section{(Estudos da substituição do íon $\mathrm{Sr}^{2+}$ nas propriedades ferroelétricas $e$ piezoelétricas do PZT nanocristalino)}

\author{
P. Kour, S. K. Sinha \\ Department of Applied Physics, Birla Institute of Technology, Patna-800014 \\ paramjit_7914@rediffmail.com,drsanjay18@yahoo.co.in
}

\begin{abstract}
Strontium substituted lead zirconate titanate nanocrystalline material with chemical formula $\mathrm{Pb}_{0.95} \mathrm{Sr}_{0.05}\left(\mathrm{Zr}_{0.52} \mathrm{Ti}_{0.48}\right) \mathrm{O}_{3}$ have been synthesized by alkoxide based sol gel method. The product was characterized by differential thermal analysis, thermogravimetric analysis, powder X-ray diffraction and scanning electron microscopy. The ferroelectric hysteresis loop measurement was carried out at room temperature using ferroelectric loop tracer over a field range of $20 \mathrm{kV} / \mathrm{cm}$. The remanent polarization $\mathrm{P}_{\mathrm{r}}$, saturation polarization $\mathrm{P}_{\max }$ and coercive field $\mathrm{E}_{\mathrm{c}}$ were $12.97 \mu \mathrm{C} / \mathrm{cm}^{2}, 30.52 \mu \mathrm{C} / \mathrm{cm}^{2}$ and $6.5 \mathrm{kV} / \mathrm{cm}$ respectively. The piezoelectric coefficient $\mathrm{d}_{33}$ was measured with the variation of polling field.
\end{abstract}

Keywords: ferroelectric properties, nanocrystallite, polarization, PSZT.

\section{Resumo}

O material nanocristalino titanato zirconato de chumbo com substituição por estrôncio de fórmula química $P b_{0,95} S_{0,05}\left(Z_{0,52} T_{0,48}\right) O_{3}$ foi sintetizado pelo método solgel baseado em alcóxidos. O produto foi caracterizado por análise térmica diferencial, análise termogravimétrica, difração de raios X e microscopia eletrônica de varredura. A medida do loop de histerese ferroelétrica foi feita

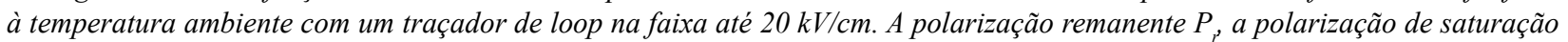
$P_{\max }$ e o campo coercitivo $E_{c}$ foram $12,97 \mu \mathrm{C} / \mathrm{cm}^{2}, 30,52 \mu \mathrm{C} / \mathrm{cm}^{2}$ e $6,5 \mathrm{Kv} / \mathrm{cm}$, respectivamente. O coeficiente piezoelétrico $d_{33}$ foi medido em função do campo de polarização.

Palavras-chave: propriedades ferroelétricas, nanocristalito, polarização, PSZT.

\section{INTRODUCTION}

Ferroelectric materials have been intensively investigated in the last decades for their potential applications in a variety of electronics application; including non-volatile memories and MEMS devices [1-5]. The nonvolatile ferroelectric random access memories have been drawn considerable interest in which the information is stored in the polarization states of ferroelectrics. PZT with stichometry formula $\mathrm{Pb}\left(\mathrm{Zr}_{0.52} \mathrm{Ti}_{0.48}\right) \mathrm{O}_{3}$ is reported to be near the morphotropic phase boundary (MPB) shows large remanent polarization, optimum piezoelectric property and high Curie temperature [6, 7]. The MPB is an almost temperature-independent phase boundary that separates two ferroelectric phases: a tetragonal crystal structure $(P 4 \mathrm{~mm})$ and a rhombohedral structure $(R 3 \mathrm{c})$. Compositions near the MPB may have both of these phases coexisting to give a total of fourteen possible polarization directions (six tetragonal $<001>$ and eight rhombohedral $<111>$ in reference to the cubic prototype cell axes.

The possibilities of improving ferroelectric and piezoelectric properties of ceramics by physico-chemical characteristics of precursors, additive type and proper selection of parameter of sintering process $[8,9]$. By using different of types additive the properties of the PZT system can be changed. Donor and acceptor doping are used to obtain so-called "soft" and "hard" PZT materials, respectively [10-16].There are several substitution of elements ( $\mathrm{La}, \mathrm{Nd}$, etc.) on $\mathrm{Pb}$ side gives rise to hard and soft PZT. [16-18]. In the present paper the study was based on isovalent substitution of strontium on lead side of the PZT. Here the doping was done in the rhombohedral phase which haves order along [111] direction leads to a favourable piezoelectric properties [19].

The microstructure, ferroelectric and piezoelectric properties of strontium substituted lead zirconate titanate (PSZT) have been reported by various groups [23-27]. According to our knowledge there is no report on ferroelectric and piezoelectric property of the PSZT nanocrystallite in 15$16 \mathrm{~nm}$ range. The objective of this paper is to investigate the influence of condition of the sol gel process on crystallite size and the effect of crystallite size on the ferroelectric and piezoelectric property of PZT doped with strontium (PSZT) at $\mathrm{MPB}$ i.e. $\mathrm{Zr} / \mathrm{Ti} \approx 52 / 48$. 


\section{EXPERIMENTAL}

A compositions with the general chemical formula $\mathrm{Pb}_{0.95} \mathrm{Sr}_{0.05}\left(\mathrm{Zr}_{x} \mathrm{Ti}_{1-x}\right) \mathrm{O}_{3}$ was prepared using sol gel processing routes, with $x$ corresponding to different crystalline modifications of the ferroelectric phase: tetragonal $(x=0.52)$, rhombohedral $(x=0.48)$ [1]. 2-Methoxy ethanol (2-MOE) was used as the starting precursor. Lead (II) acetatetrihydrate $(99.99 \%$ purity, Aldrich), zirconium (IV) isopropoxide (70 wt.\% purity , Aldrich) and titanium (IV) isopropoxide (97\% purity, Aldrich) were used as the starting reagents to prepare the precursor solution with stichometry $\mathrm{Pb}_{0.95} \mathrm{Sr}_{0.05}\left(\mathrm{Zr}_{0.52} \mathrm{Ti}_{0.48}\right) \mathrm{O}_{3}$ and strontium acetate (99\% purity, Aldrich) was used as $\mathrm{Sr}$ source. The flow diagram for the preparation of PSZT gel is shown in the Fig. 1. 2-Methoxy ethanol mixed with acetyl acetone and stirred at room temperature for $0.5 \mathrm{~h}$. Ti-isopropoxide was added to it while the temperature of the stirred solution was kept at $80^{\circ} \mathrm{C}$. After $1 \mathrm{~h}$ the $\mathrm{Zr}$-isopropoxide was added to the heated stirred solution. After $1 \mathrm{~h}$ strontium acetate was added to it. Then lead acetate trihydrate was mixed with distilled water and added to the solution. Then it was refluxed at $80{ }^{\circ} \mathrm{C}$ for $3 \mathrm{~h}$. At last 3 to 4 drops of nitric acid was added to it. The solution was again refluxed for $3 \mathrm{~h}$ at $80^{\circ} \mathrm{C}$. Then it was stirred room temperature to get slightly yellowish clear transparent sol. It was then heated and stirred at $80^{\circ} \mathrm{C}$ to get the gelation of PSZT sol.

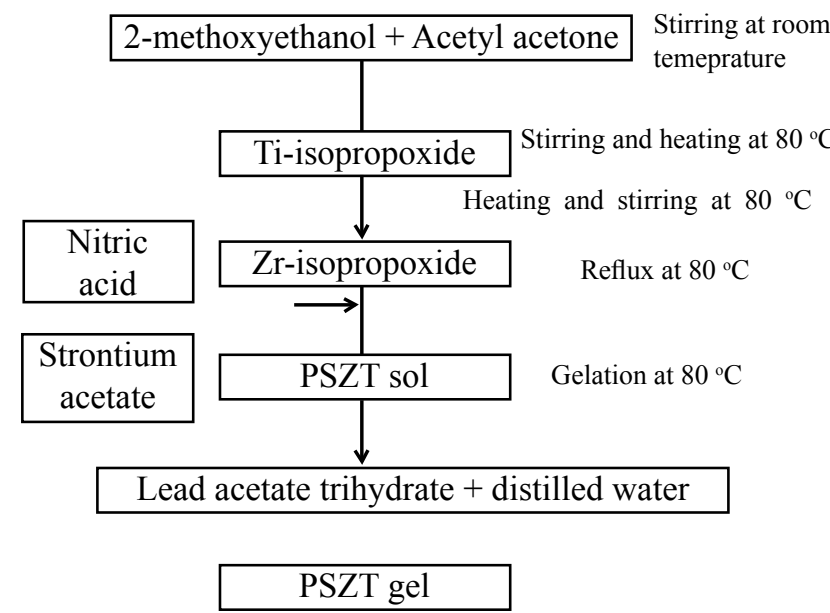

Figure 1: Flow diagram for obtaining the PSZT gel.

[Figura 1: Fluxograma da obtenção do gel de PSZT.]

Differential thermal analysis (DTA) and thermogravicmetric analysis (TGA) of the green gel in a temperature range $100{ }^{\circ} \mathrm{C}-1000{ }^{\circ} \mathrm{C}$ at a heating rate of $10{ }^{\circ} \mathrm{C} / \mathrm{min}$ was carried out to know the approximate calcination temperature. The phase purity and homogeneity of the obtained material was determined by powder X-ray diffractometry. X-ray diffraction (XRD) measurements were performed at $2 \theta$ values ranging from $15^{\circ}$ and $70^{\circ}$ using Philips X-ray diffractometer with Ni- filtered Cuk $\alpha$ radiation. The nanocrystalline PSZT calcined powder was granulating and mixed with polyvinylalchol (PVA, 5\% aqueous solution) in a mortar and pestle. The mixed powder was compacted to circular discs of $12 \mathrm{~mm}$ in diameter and $\sim 1.5 \mathrm{~mm}$ in thickness by uniaxial pressing machine at $200 \mathrm{MPa}$. The binder was removed by heating the pellet at $550{ }^{\circ} \mathrm{C}$. Then binder burnout components were sintered at $1000^{\circ} \mathrm{C}$ for $3 \mathrm{~h}$ in a hermetically sealed alumina crucible in a muffle furnace. The surface morphology of the sintered samples was analysed using scanning electron microscope (SEM, Jeol T330). Energy dispersive X-ray analysis (EDX) was used for elemental analysis of $\mathrm{Sr}$ doped PZT ceramics. The electroding of the sintered pellet was done by the silver paste. Then the sample was poled at varying polling field at an elevated temperature $(\sim 120$ ${ }^{\circ} \mathrm{C}$ ) for $2 \mathrm{~h}$ in silicon oil. The polarization-electric field (PE) hysteresis measurement of poled PSZT pellet was done by Radiant Technology Hysteresis Analyser 4.4.0 at room temperature. The linear piezoelectric coefficient $\left(\mathrm{d}_{33}\right)$ of the polled pellet was measured by the Sinocera YE2730Ad meter with the variation of polling field.

\section{RESULTS AND DISCUSSION}

\section{DTA/TG characterization}

Thermal analysis of the green gel of PSZT (5/52/48) was examined by thermo gravimetry and differential thermal analysis, shown in Fig. 2. The weight loss occurred in two steps and completed at $600{ }^{\circ} \mathrm{C}$, as indicated by TGA curves. In the first stage weight loss was observed around $90{ }^{\circ} \mathrm{C}$ with an endothermic peak due to the removal of water molecules. In the second stage a small exothermic peak was observed around $300{ }^{\circ} \mathrm{C}$ due to the result of simultaneous decomposition of organic molecule. A large exothermic peak at $377{ }^{\circ} \mathrm{C}$ is ascribed to multiple decomposition. The percentage of weight loss at $600{ }^{\circ} \mathrm{C}$ and above was very small; hence calcination had been done at $600{ }^{\circ} \mathrm{C}$ for a soaking time $3 \mathrm{~h}$.

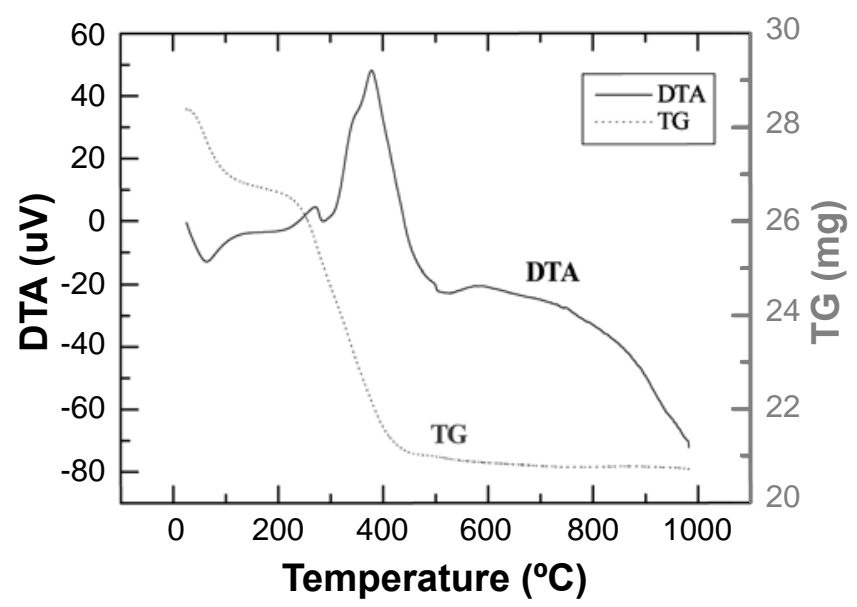

Figure 2: DTA/TG curve of PSZT sample.

[Figura 2: Curvas ATD/TG da amostra de PSZT.] 


\section{$X R D$ characterization}

Fig. 3 shows the powder XRD pattern of PZT doped with strontium, PSZT (5/52/48).

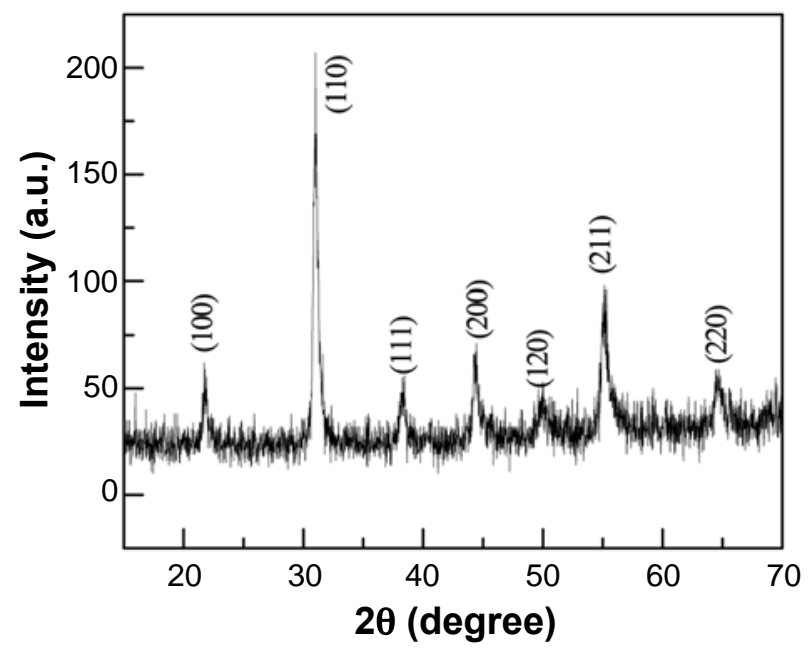

Figure 3: XRD diffraction pattern of PSZT calcined powder. [Figura 3: Difratograma de raios X do pó calcinado de PSZT.]

The pattern shows a pure crystalline perovskite phase with no pyrochlore phase. The average crystallite size has been calculated using Scherrer formula and WilliamsonHall plot. Scherrer formula [20] is defined as

$$
\mathrm{D}=\frac{\mathrm{k} \lambda}{\beta \cos \Theta}
$$

where the constant $\mathrm{k}$ depends upon the shape of the crystallite size ( $=0.89$, assuming circular grains), $\beta$ is the full width at half maximum (FWHM) of intensity (a.u.) vs. $2 \theta$ (degree) profile, $\lambda$ is the wavelength of the $\mathrm{Cuk}_{\alpha}$ radiation $(=0.1542$ $\mathrm{nm}), \theta$ is Bragg diffraction angle and $\mathrm{D}$ is the average crystallite size. In Scherrer formula the average crystallite size has been calculated using Gaussian fit to the peaks in XRD pattern. D has been taken as average to all the peaks.

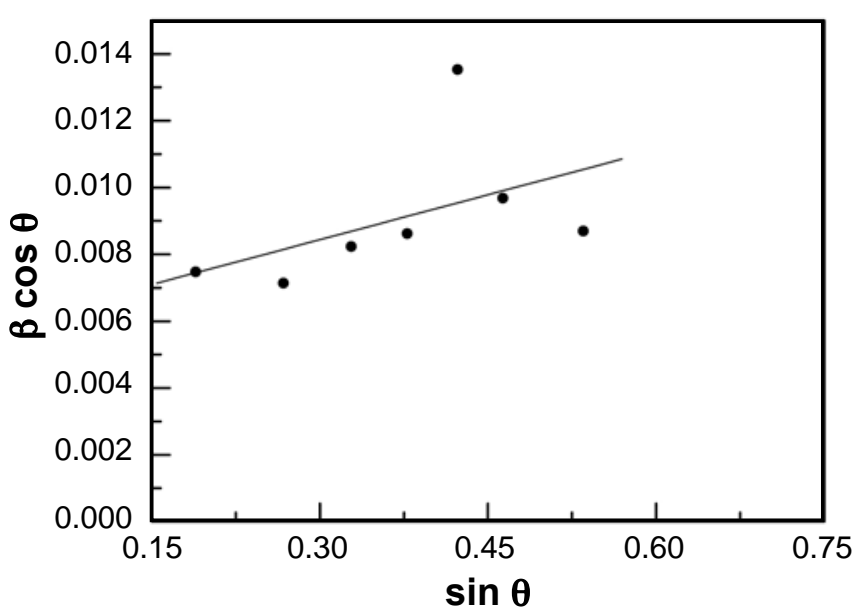

Figure 4: Williamson-Hall plot of PSZT powder.

[Figura 4: Gráfico de Williamson-Hall do pó de PSZT.]
Typical Williamson-Hall plot for PSZT (5/52/48) sample is displayed in Fig. 4. According to this method [21, 22] the individual contributions to the broadening of reflections can be expressed as

$$
\beta \cos \Theta=\frac{\mathrm{k} \lambda}{\mathrm{D}}+4 \varepsilon \sin \Theta
$$

The strain effect on the crystallites is represented by $4 \varepsilon \cdot \sin \theta$. Average crystallite sizes calculated by Scherrer formula were $16.16 \mathrm{~nm}$ and Williamson-Hall plot was $15.98 \mathrm{~nm}$. The crystallite size obtained by Williamson-Hall method was less than those obtained by Scherrer formula. It was because the strain correction factor has been taken into account in case of Williamson-Hall method whereas it has not been taken into account in Scherrer's method.

\section{SEM characterization}

The scanning electron microscopy micrograph of PSZT $(5 / 52 / 48)$ pellet sintered at $1000{ }^{\circ} \mathrm{C}$ for $8 \mathrm{~h}$ is shown in Fig. 5. Qualitatively it is observed that grains were uniformly distributed. The average grain size measured from the micrograph of the pellet is about $307.4 \mathrm{~nm}$.

The EDX spectra of 5\% Sr doped PZT pellet sintered at $1000{ }^{\circ} \mathrm{C}$ is shown in Fig. 6. The presence of constituent

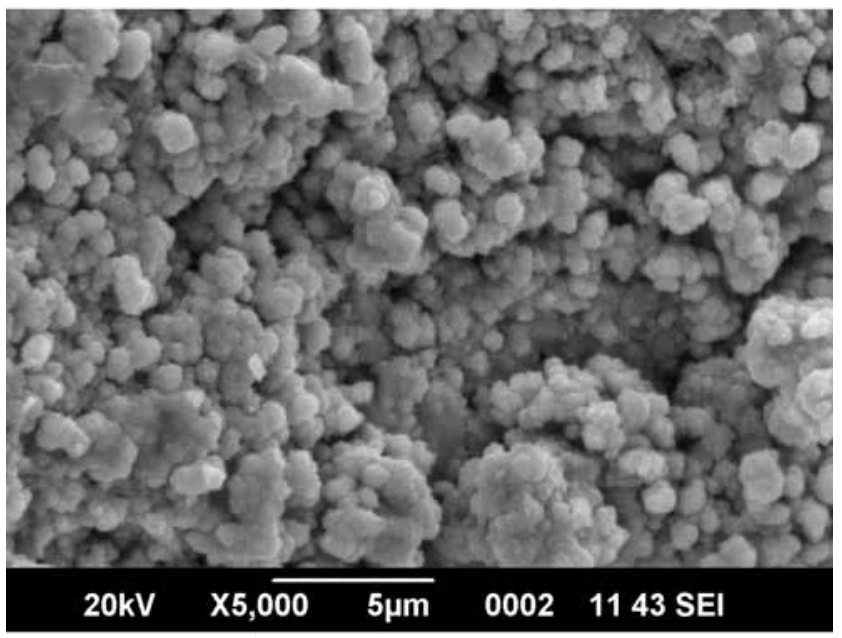

Figure 5: SEM image of PSZT sample.

[Figura 5: Imagem MEV da amostra PSZT.]

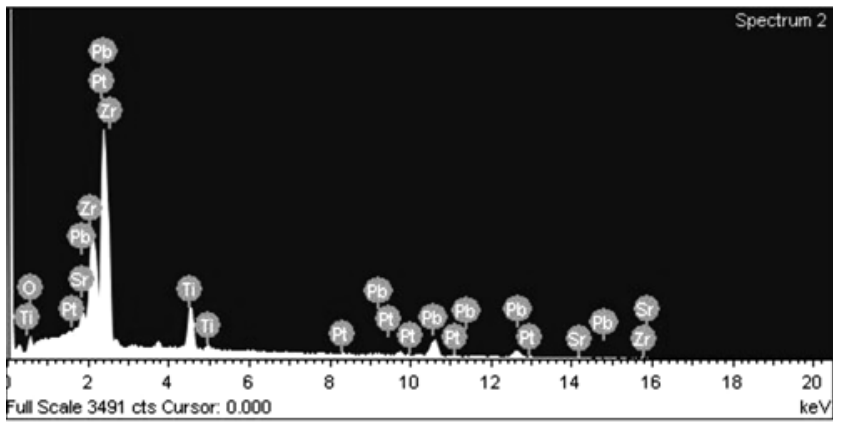

Figure 6: EDX microanalysis of the PSZT pellet.

[Figura 6: Microanálise EDX da cerâmica de PSZT.] 
element in PSZT pellet is indicated by the peak of $\mathrm{Pb}, \mathrm{Zr}$, $\mathrm{Ti}, \mathrm{Sr}$ and $\mathrm{O}$. The top electrode of the pellet was made of $\mathrm{Pt}$, which is an also peak appearing in Fig. 6. So it could be attested that the PSZT ceramic was formed.

Ferroelectric hysteresis (P-E loop) of the PSZT (5/52/48) pellet calcined at $1000{ }^{\circ} \mathrm{C}$ is presented in Fig. 7. The average remanent polarization, $\left(1+\mathrm{P}_{\mathrm{r}}|+|-\mathrm{P}_{\mathrm{r}} \mid\right) / 2$ of the PSZT pellet is $12.97 \mu \mathrm{C} / \mathrm{cm}^{2}$. The average coercive field, $\left(1+\mathrm{E}_{\mathrm{C}} \mathrm{I}+\mathrm{I}-\mathrm{E}_{\mathrm{C}} \mathrm{I}\right) / 2$ for PSZT pellet is $6.5 \mathrm{kV} / \mathrm{cm}$. The saturation polarization $\left(\mathrm{P}_{\max }\right)$ of the pellet is $30.52 \mu \mathrm{C} / \mathrm{cm}^{2}$.

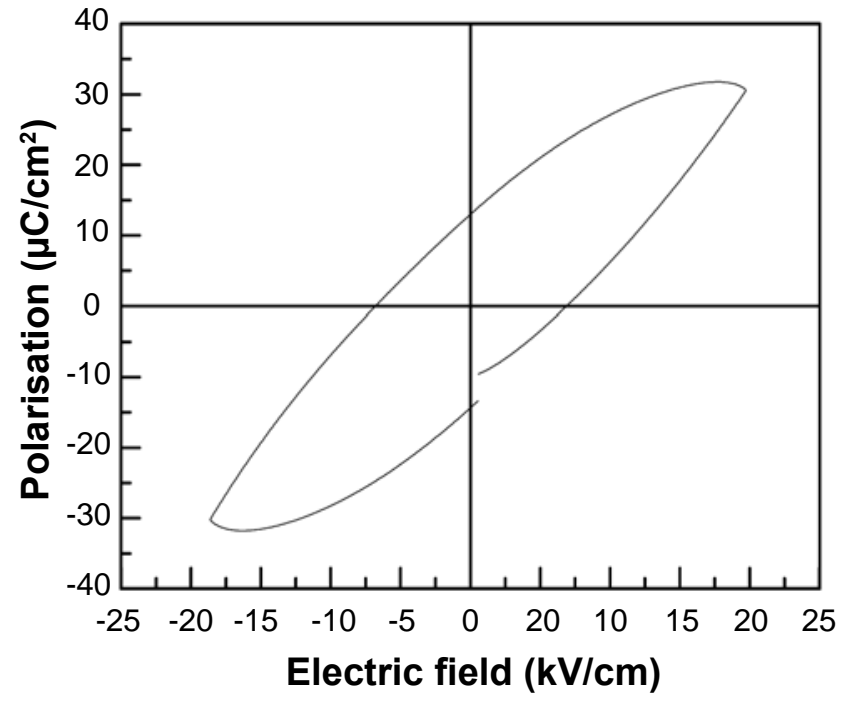

Figure 7: P-E loop of PSZT pellet.

[Figura 7: Loop P-E loop da cerâmica de PSZT.]

Fig. 8 shows the variation of piezoelectric coefficient $\left(d_{33}\right)$ of PSZT $(5 / 52 / 48)$ pellet with varying polling field. It is observed that with increasing the polling field, the piezoelectric co-efficient $\left(\mathrm{d}_{33}\right)$ increases. Maximum value of piezoelectric co-efficient $\left(\mathrm{d}_{33}\right)$ is $413 \times 10^{-12} \mathrm{C} / \mathrm{N}$ at $33 \mathrm{kV} /$ $\mathrm{cm}$ polling field. With further increase in the polling field

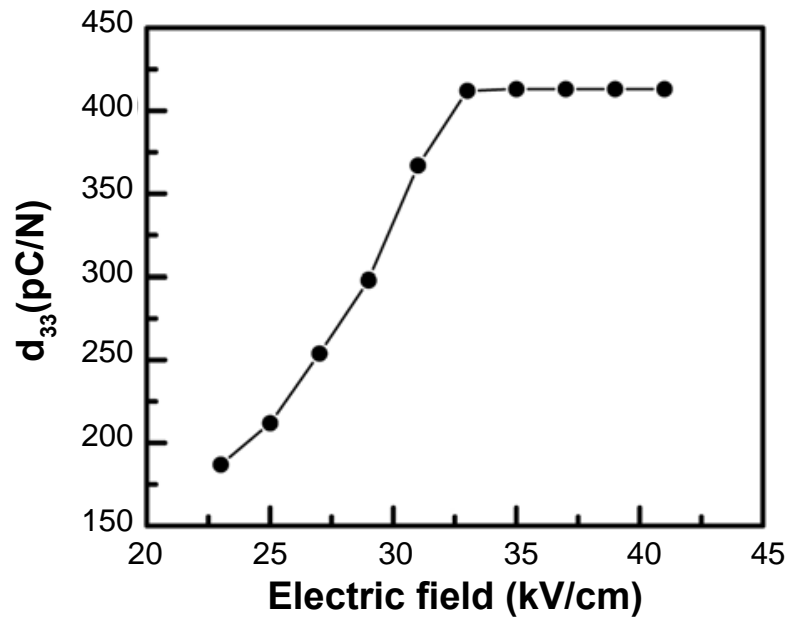

Figure 8: Piezoelctric co-efficient $\left(\mathrm{d}_{33}\right)$ of PSZT pellet with the variation of polling field.

[Figura 8: Coeficiente piezoelétrico $\left(d_{33}\right)$ da amostra PSZT em função do campo de polarização.] it remains almost same. It indicates the orientation of the domain reaches its final alignment here.

\section{CONCLUSIONS}

Nanocrystallite of PSZT (5/52/48) has been successfully synthesized by the sol gel process. The thermogravimetric curve of the green gel of PSZT (5/52/48) shows the percentage of weight loss at $600{ }^{\circ} \mathrm{C}$ and above it is very small. Hence calcinations have been done at $600{ }^{\circ} \mathrm{C}$. The XRD of PSZT $(5 / 52 / 48)$ powder shows the average crystallite size was in $15-16 \mathrm{~nm}$ range. The average grain size from SEM was also obtained in nano range. The piezoelectric and ferroelectric property enhance, due to the decrease in size of the average crystallite. Reasons for this could be related to processing and the control of grain boundary resistivity that lead to space-charge accumulation, which marks the size-effect response in the ferroelectric grains.

\section{REFERENCES}

[1] E. M. Lines, A. M. Glass, Principles and applications of ferroelectric and related materials, Cleardon, Oxford, UK (1977).

[2] G. H. Haertling, "Piezoelectricity and electro-optics ceramics", Ceramic Materials for Electronics, Ed.: R. C. Buchanan, Marcel Dekker, New York, USA (1986) p. 168 [3] L. Benguigui, On the properties of PZT solid solutions: a reply to a comment, Solid State Comm. 19 (1986) 979-981. [4] Y. Xu, Ferroelctric materials and their applications, North Holland, New York, USA (1991) 72-100.

[5] R. E. Newnham, G. R. Ruschau, J. Am. Ceram. Soc. 74 (1991) 463.

[6] S. A. Mabud, The morphotropic phase boundary in PZT solid solutions, J. Appl. Crystal. 13 (1980) 211-216.

[7] V. A. Isopov, Characteristics of coexistence of tetragonal rhombohedral phases in piezoelectric ceramics based on $\mathrm{PbTiO}_{3}$ and $\mathrm{PbZrO}_{3}$, Sov. Phys.- Solid State 18, 4 (1976) 529-532.

[8] T. Yamamoto, Optimum Preparation Methods for Piezoelectric Ceramics and their Evaluation, Am. Ceram. Soc. Bull. 71 (1992) 978-85.

[9] G. T. Murray, "Introduction of Engineering Materials", Marcel Dekker, New York, USA (1993) 479-534.

[10] G. H. Haertling, Am. Ceram. Soc. Bull. 43 (1964) 875879.

[11] M. Pisarski, Ferroelectrics 81 (1988) 297-300.

[12] A. H. Webster, T. B. Weston, J. Can. Ceram. Soc. 37 (1968) 51-54.

[13] H. Ouchi, K. Nagano, S. Hayakawa, J. Am. Ceram. Soc. 48 (1965) 630-635.

[14] H. T. Martirena, J. C. Burfoot, J. Phys. C: Solid State Phys. 7 (1974) 3182-9312.

[15] K. Keizer, E. H. Janssen, K. J. de Vries, A. J. Burggraaf, Mater. Res. Bull. 8 (1973) 533-544.

[16] A. J. Burggraaf, K. Keizer, Mater. Res. Bull. 10 (1975) 521-528. 
[17] A. K. Shukla, V. K. Agrawal, I. M. L. Das, Janardansingh, S. L. Srivastava, Bull. Mater. Sci. 34, 1 (2011) 133-142.

[18] Uta Helbig, J. Eur. Ceram. Soc. 7 (2007) 2567-2576.

[19] R. S. Nasar, M. Cerqueira, E. Longo, J. A. Varela, A. Beltran, J. Eur. Ceram. Soc. 22 (2002) 209-218.

[20] B. D. Culity, "Elements of X-ray Diffraction", 2 ${ }^{\text {nd }}$ Ed., Addison-Wesley, USA (1978).

[21] G. K. Williamson, W. H. Hall, Acta Met. 1 (1953) 22.

[22] C. Suryanarayana, M. Grant Nortan, "X-ray Diffraction: A Practical Approach", Plenum Publ. Corp., New York, USA (1998).
[23] R. Lal, S. C. Sharma, R. Dayal, Ferroelectrics 100, 1 (1989) 43-55.

[24] F. Kulcsar, J. Am. Ceram. Soc. 42, 1 (1959) 49-51. [25] A. Dalakoti, A. Bandyopadhyay, S. Bose, J. Am. Ceram. Soc. 89, 3 (2006) 1140-1143.

[26] M. Khalid, M. Shoaib, A. A. Khan, J. Nanosci, Nanotech. 11, 6 (2011) 5440-5445.

[27] C. Bedoya, Ch. Mullerb, J.-L. Baudour, V. Madigou, M. Anne, M. Roubin, Mater. Sci. Eng. B75 (2000) 43-52.

(Rec. 23/11/2011, Rev. 01/01/2012, 04/04/2012, Ac. $05 / 05 / 2012)$ 